Research paper

\title{
Characterization of clays from the Corumbataí formation used as raw material for ceramic industry in the Santa Gertrudes district, São Paulo, Brazil
}

\author{
Andrezza de Almeida Azzi ${ }^{\text {a,*,1 }}$, Marek Osacký ${ }^{\text {b,1 }}$, Peter Uhlík ${ }^{\text {b }}$, Mária Čaplovičová b,c \\ Antenor Zanardo ${ }^{\mathrm{d}}$, Jana Madejová ${ }^{\mathrm{e}}$ \\ a CAPES Foundation, Ministry of Education of Brazil, 70040020 Brasília, DF, Brazil \\ b Department of Economic Geology, Comenius University, Faculty of Natural Sciences, Mlynská dolina, Ilkovičova 6, 84215 Bratislava, Slovak Republic \\ c Slovak University of Technology, Centre for Nanodiagnostics, Vazovova 5, 81243 Bratislava, Slovak Republic \\ d Department of Petrology and Mineralogy, University of São Paulo State UNESP, 13506900 Rio Claro, SP, Brazil \\ e Institute of Inorganic Chemistry, Slovak Academy of Sciences, Dúbravská cesta 9, 84536 Bratislava, Slovak Republic
}

\section{A R T I C L E I N F O}

\section{Article history:}

Received 24 February 2016

Received in revised form 4 May 2016

Accepted 15 June 2016

Available online 18 June 2016

\section{Keywords:}

Mineral composition

Clayey rock

Weathering

Tilemaking

Technological behavior

\begin{abstract}
A B S T R A C T
The Ceramic District of Santa Gertrudes (CDSG) is the largest producer of ceramic floor and wall tiles in Brazil. Tile manufacturers in the CDSG use the single raw material, clayey rocks from the Corumbataí formation. Mineralogical, chemical, thermal and microstructural characterization of the clayey rocks from the Corumbataí formation have been performed in order to better understand effect of the studied properties on dry route tilemaking process. The results revealed different compositional features among the studied clayey raw materials. The bulk samples were dominated by clay minerals associated with quartz, feldspars and minor amount of hematite. All samples were complex mixtures where different types of clay minerals (illite, smectite, illite-smectite, kaolinite-smectite, chlorite, sometimes kaolinite) coexist in variable amount. The amount of clay minerals increased with a higher degree of weathering of studied samples. Different technological behavior was expected for studied raw materials due to their heterogeneous nature, in terms of mineral composition and weathering degree. To improve technological behavior of studied materials during tilemaking process an upgrade of the currently used raw materials preparation is recommended (raw materials maturation, more aggressive milling of raw materials, addition of plastic component and homogeneous mixing of plastic and non-plastic components).
\end{abstract}

(c) 2016 Elsevier B.V. All rights reserved.

\section{Introduction}

The Ceramic District of Santa Gertrudes (CDSG), located in the state of São Paulo, Brazil, is the largest producer of ceramic floor and wall tiles in Brazil. The ceramic tiles production in Brazil reached almost 1 billion $\mathrm{m}^{2}$ in 2014 and the CDSG accounted for about 60\% of the total tiles production (ANFACER, 2014). Such a large tiles production implies high demand for raw materials. In 2013, almost 9 million tons of clayey raw materials was consumed in the CDSG, assuming the average tile weight of $13 \mathrm{~kg} / \mathrm{m}^{2}$ (Cabral et al., 2013). The use of clayey raw materials in tile manufacturing depends on the technological and appearance requirements of ceramic body such as color after firing and behavior during the tilemaking process, which are intimately connected with mineral composition, chemical composition and particle size

\footnotetext{
* Corresponding author at: Av. Nelsia Vannucci 105, ap113 Girassol, 13042104 Campinas, SP, Brazil.

E-mail address: andrezzazzi@gmail.com (A. de Almeida Azzi).

1 Indicates equal contribution.
}

distribution (Dondi, 1999). The tile manufacturers in the CDSG use only raw materials from the Corumbataí formation. Illite, smectite, kaolinite, quartz, feldspars, hematite and iron hydroxides have been reported as the main mineral constituents of clayey raw materials from the Corumbataí formation (Motta et al., 2007).

The characteristic feature of tilemaking in Brazil is applying of dry route manufacturing process. In the CDSG, approximately $73 \%$ of tile manufactures use the dry route process to make tiles. The current dry route tilemaking process in the CDSG consists of several basic steps: body preparation, involving mixing of different types of clayey raw materials from the Corumbataí formation, drying of the clay mixture by sunlight to $5.5 \%$ moisture, dry grinding and granulation of clay mixture at around $10 \%$ moisture; tile shaping by hydraulic presses; tile drying by fast cycles in vertical or horizontal driers; tile glazing and decoration; and tile firing by fast cycles in roller kilns (up to $1150^{\circ} \mathrm{C}$ for $20 \mathrm{~min}$ ). The final products are ceramic tiles of reddish color, glazed surface and water absorption between 6 and 10 wt.\%, classified by the ISO 13006 technical standard as class $\mathrm{BII}_{\mathrm{b}}$ (Motta et al., 2007). The main advantage of dry route tilemaking process is a lower energy consumption that lowers 
production costs compared with traditional wet route tilemaking process.

On the other hand, dry grinding of clayey raw material during the dry route tilemaking process has several shortcomings, most significant of which are increased levels of dust in the air and rivers, which cause breathing problems and lower the water quality in the rivers. As a result, the Brazil government requires a replacement of outdoor drying of raw material in the courtyards of mines using sunlight energy by indoor forced drying using industrial dryers. However, change of the drying process has changed the technological behavior of some raw materials during tilemaking process. The formation of cracks and fissures was observed by local manufacturers for several ceramic tiles made up of the clayey raw materials which were pre-treated by indoor forced drying. A deep understanding of the nature of clayey raw material is essential to recognize the distinct technological behavior of clayey rocks during tilemaking process to achieve the optimal industrial utilization and to minimize the environmental problems.

Previous studies have shown that besides variability in mineral and chemical composition, a different degree of weathering of clayey rocks from the Corumbataí formation affects the physico-chemical properties which in turn may account for unexpected behavior of clayey raw materials during tilemaking (Zanardo, 2003; Rocha, 2012; Moreno et al., 2014). As a consequence, the manufacturers in the CDSG usually mix several different types of clayey rocks from the Corumbataí formation together in order to prepare a batch of optimal composition. Such treatment should ensure similar quality of the final ceramic products.

Moreno et al. (2014) investigated relationships among the chemical and mineral composition of clayey rocks from the Corumbataí formation and technological properties of ceramic bodies prepared from the clayey rocks. The authors distinguished three types of clayey raw materials which displayed distinct mineral and chemical composition due to different degree of weathering of the rocks. Differences in mineral composition and degree of weathering of raw materials influenced the packaging of mineral particles during pressing of ceramic bodies which resulted in different mechanical resistance of ceramic products prepared from the three types of raw materials.

In contrast to previous studies, different size fractions of the clayey rocks from the Corumbataí formation were investigated in the present study besides bulk fraction, with emphasis on clays and clay minerals. The aim of the present study was to perform mineralogical, chemical, thermal and microstructural characterization of clayey rocks from the Corumbataí formation, used as a raw material for ceramic industry in the CDSG, in order to better understand effect of the studied properties on the dry route tilemaking process in the CDSG.

In this paper, the results of comprehensive characterization of clayey raw materials itself are reported. The results of laboratory experiment and large-scale technological test conducted on the same set of samples pre-treated by sunlight drying and forced drying will be reported in a separate paper.

\section{Geological settings}

The studied samples were collected from the Corumbataí formation in the northeast Paraná Basin in the CDSG area (Fig. 1a). The Paraná Basin is composed of a thick $(<6800 \mathrm{~m})$ sedimentary-magmatic sequence that covers $\sim 1,700,000 \mathrm{~km}^{2}$ in central-eastern South America. Six supersequences have been recognized in the Paraná Basin by Milani et al. (2007). The Corumbataí formation is the upper part of the Permian Passa Dois Group, which is part of the supersequence Gondwana I (Fig. 1b).

In the CDSG, the Corumbataí formation is about $100 \mathrm{~m}$ thick consisting predominantly of claystones, shales, siltstones and sandstones (Fig. 2). Most of the sediments in the Corumbataí formation were probably deposited in shallow marine intertidal and lagoonal environments (e.g. Ramos and Formoso, 1976; Petri and Coimbra, 1982). The presence of non-marine fossils (e.g. ostracodes) in these strata indicates the existence of rivers that drained from the north into the Paraná Basin and freshened its margins (Sohn and Rocha-Campos, 1990).

After exposure of the Corumbataí formation (end of Tertiary) weathering processes took place. The mineral alterations and changes on physico-chemical properties of the rocks associated with the weathering processes have been reported by Zanardo (2003). It is believed that different degree of supergene weathering of clayey rocks from the Corumbataí formation affected the mineral and chemical composition. Accordingly, different degree of weathering modifies the grain size after grinding, plasticity, bending strength and the sintering of the raw material, which may have led to the distinct technological behavior of clayey raw materials during tilemaking process (Rocha, 2012).

\section{Starting materials and methods}

\subsection{Starting materials}

Three types of clayey rocks of different degree of weathering (D hard, I - intermediate and $\mathrm{M}$ - soft) from the Corumbataí formation were examined in this study. "Hard", " intermediate" and "soft", are terms indicating different degree of compactness of the studied samples. These samples were recognized by the ceramic manufacturers as ones of the worst technological types of raw materials used in the CDSG. Samples D and I come from Alfagres mine, M is from Pieroni mine. Stratigraphic position of the samples D, I and M within the Corumbataí formation is shown in Fig. 2.

The as-received samples D, I and M were dried at room temperature overnight and crushed to pass through a $160 \mu \mathrm{m}$ sieve. The clay fraction $(<2 \mu \mathrm{m})$ was separated from the bulk samples by sedimentation in distilled water. The modified Jackson treatment by Šucha et al. (1991) was applied for all clay fractions isolated from the bulk D, I and M. After Jackson treatment, the size fractions $2-0.2 \mu \mathrm{m}$ and $<0.2 \mu \mathrm{m}$ were isolated from the clay fraction $(<2 \mu \mathrm{m})$ by centrifugation. The fine size fractions $(<2 \mu \mathrm{m}, 2-0.2 \mu \mathrm{m}$ and $<0.2 \mu \mathrm{m})$ were treated four times overnight with $0.1 \mathrm{M} \mathrm{CaCl}_{2}$ and $1 \mathrm{M} \mathrm{NaCl}$ (Moore and Reynolds, 1997). Excess soluble salts were removed by centrifugation followed by dialysis. The fine size fractions were dried overnight at $60{ }^{\circ} \mathrm{C}$, ground gently in an agate mortar and analyzed.

\subsection{Methods}

The XRD patterns of oriented and randomly oriented preparations were recorded using a Phillips PW 1710 diffractometer with $\mathrm{Cu}$ K $\alpha$ radiation and graphite monochromator at $20 \mathrm{~mA}$ and $35 \mathrm{kV}$. The step size for all analyses was $0.02^{\circ} 2 \theta$. The XRD patterns of oriented preparations with an exposure time of $0.80 \mathrm{~s}$ per step were utilized for clay minerals identification. The preparation of oriented preparations was according to Millipore filter transfer method (Moore and Reynolds, 1997).

Quantitative X-ray diffraction (QXRD) was performed on randomly oriented preparations using RockJock software (Eberl, 2003). Samples were prepared according to a method modified (Omotoso and Eberl, 2009) from that reported by Eberl (2003).

The chemical composition was determined by inductively coupled plasma (ICP) analysis after digestion of samples using lithium metaborate fusion, followed by nitric acid leaching. The analytical procedure followed the standard methods at ACME Analytical Laboratories Ltd. (Vancouver, British Columbia, Canada).

Thermal analysis was performed using a TA Instruments 2690 TG/ DTA/DSC simultaneous analyzer STA 449 F1 Jupiter (Netzsch Geratebau $\mathrm{GmbH}$ ). All measurements were performed in the temperature range of $30-1000{ }^{\circ} \mathrm{C}$ using $30 \mathrm{mg}$ of the sample holding by Pt-Ir crucible. Heating rate of $10{ }^{\circ} \mathrm{C} / \mathrm{min}$ and an air flow rate of $50 \mathrm{~m}^{3} / \mathrm{min}$ were maintained. Manipulations with collected data were performed using Netzsch Proteus software. 
a

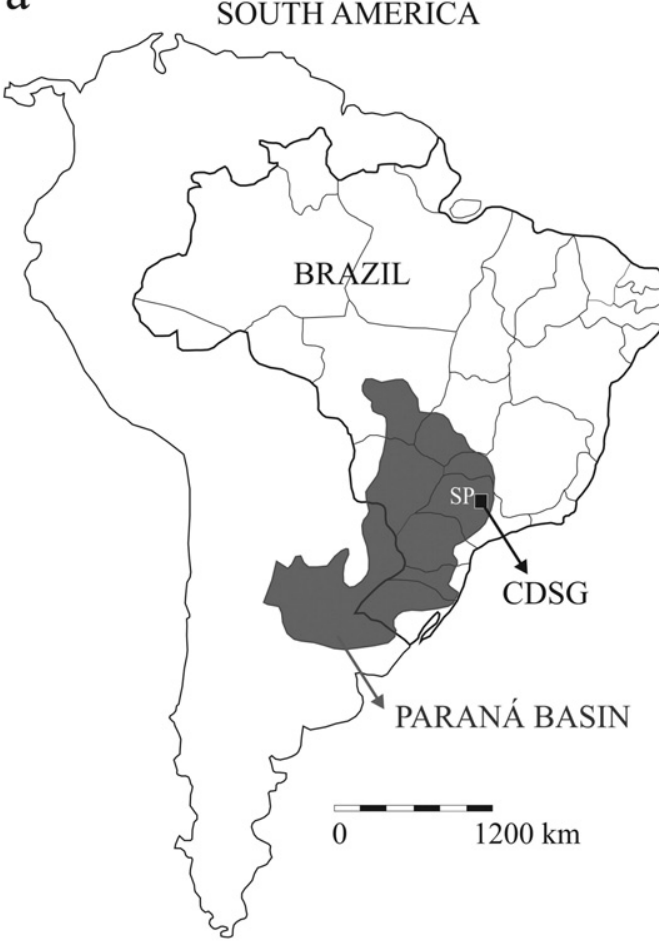

b PARANÁ BASIN (BRAZIL)

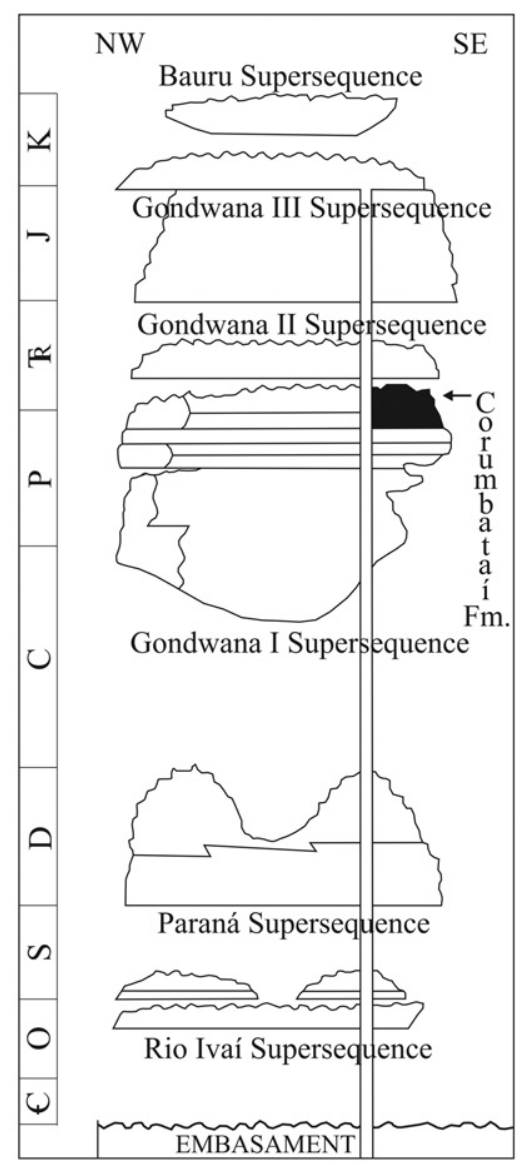

Fig. 1. Location of the Paraná Basin and the Ceramic District of Santa Gertrudes (CDSG) (a) and stratigraphy of the Paraná Basin in Brazil (Milani et al., 1994) (b).

Fourier transform infrared (FTIR) spectra in the middle infrared region (4000-400 $\mathrm{cm}^{-1}$ ) were obtained using a Nicolet 6700 spectrometer. The $\mathrm{KBr}$ pressed-disc technique was used for transmission measurements. Samples of $1 \mathrm{mg}$ were dispersed in $200 \mathrm{mg}$ of $\mathrm{KBr}$ to record optimal spectra. Discs were overnight heated at $150^{\circ} \mathrm{C}$ to minimize water absorption on $\mathrm{KBr}$ and the sample. For each sample 128 scans were recorded with a resolution of $4 \mathrm{~cm}^{-1}$. Spectral manipulations were performed using the OMNIC software package.

The petrographic study was performed on thin sections using monocular Optical Microscope Leitz (at $\times 630$ magnification). The thin sections, $30 \mu \mathrm{m}$ thick, were cut in parallel sections to linear stratification (S0). As an immersion oil, Canada balsam with refractive index $\mathrm{n}=$ 1.55 was used.

The polished thin sections prepared from bulk samples were examined by scanning electron microscopy (SEM) using a JEOL JSM 6010 LA operated at $15 \mathrm{kV}$ with an energy dispersive X-ray (EDX) detector. Prior to the observation, the surface of the samples was coated with carbon film.

Two types of samples (dispersed samples and ultrathin sections) were used for transmission electron microscopy (TEM) analysis. The preparation of the dispersed samples was according to Środoń et al. (1992). The dispersed samples were examined in TEM using a JEOL JEM-2000 FX microscope operated at $160 \mathrm{kV}$. Ultrathin sections were prepared using fragments of the dried solids $\left(\mathrm{Na}^{+}\right.$saturated, $<0.2 \mu \mathrm{m}$ ). The solids were coated with agar and immersed in water, and then embedded in resin using the method of Elsass et al. (1998). High-resolution TEM (HRTEM) was performed using a JEOL 2010 FX microscope. The number of layers per particles and particle thicknesses were measured as described by Środoń et al. (1990), at ×60,000 magnification and under focused imaging conditions.

\section{Results and discussion}

\subsection{X-ray diffraction}

The mineral composition of the bulk D, M and I samples determined by the RockJock software from randomly oriented XRD patterns (Fig. 3) is reported in Table 1 . The bulk samples were mainly composed of dioctahedral 2:1 clays (sum of illite, smectite and interstratified illitesmectite, 45-55 wt.\%) and quartz (30-32 wt.\%) with 4-15 wt.\% of feldspars (plagioclases and K-feldspars), 0-8 wt.\% of kaolinite, 1-4 wt.\% of chlorite, and $2-3$ wt.\% of hematite and 1 wt.\% of biotite. The bulk D sample contained a higher amount of feldspars and quartz and a lower amount of dioctahedral 2:1 clays and kaolinite compared with the bulk $\mathrm{M}$ and I samples. The clay minerals content was the highest (63 wt.\%) in the bulk M sample.

The XRD patterns of oriented preparations of $\mathrm{Ca}^{2+}$ saturated fine size fractions (2-0.2 $\mu \mathrm{m}$ and $<0.2 \mu \mathrm{m}$ ) were used for detailed study of clay minerals (Fig. 4 ). Smectite, illite and interstratified illite-smectite were the main clay minerals in the XRD patterns of oriented preparations $\left(\mathrm{Ca}^{2+}\right.$ saturated, $\left.<0.2 \mu \mathrm{m}\right)$ in all samples. Smectite was clearly identified by comparing diffraction patterns of air-dried and ethylene glycol (EG) solvated preparations. The air-dried XRD patterns showed a strong 001 reflection near $15.2 \AA$, which shifted to $\sim 16.9 \AA$ in the EG conditions (Fig. 4). The relative intensity of illite 001 reflection $(\mathrm{d}=$ $\sim 10.1 \AA$ ) decreased and its position slightly shifted from $\sim 10.1$ A to 


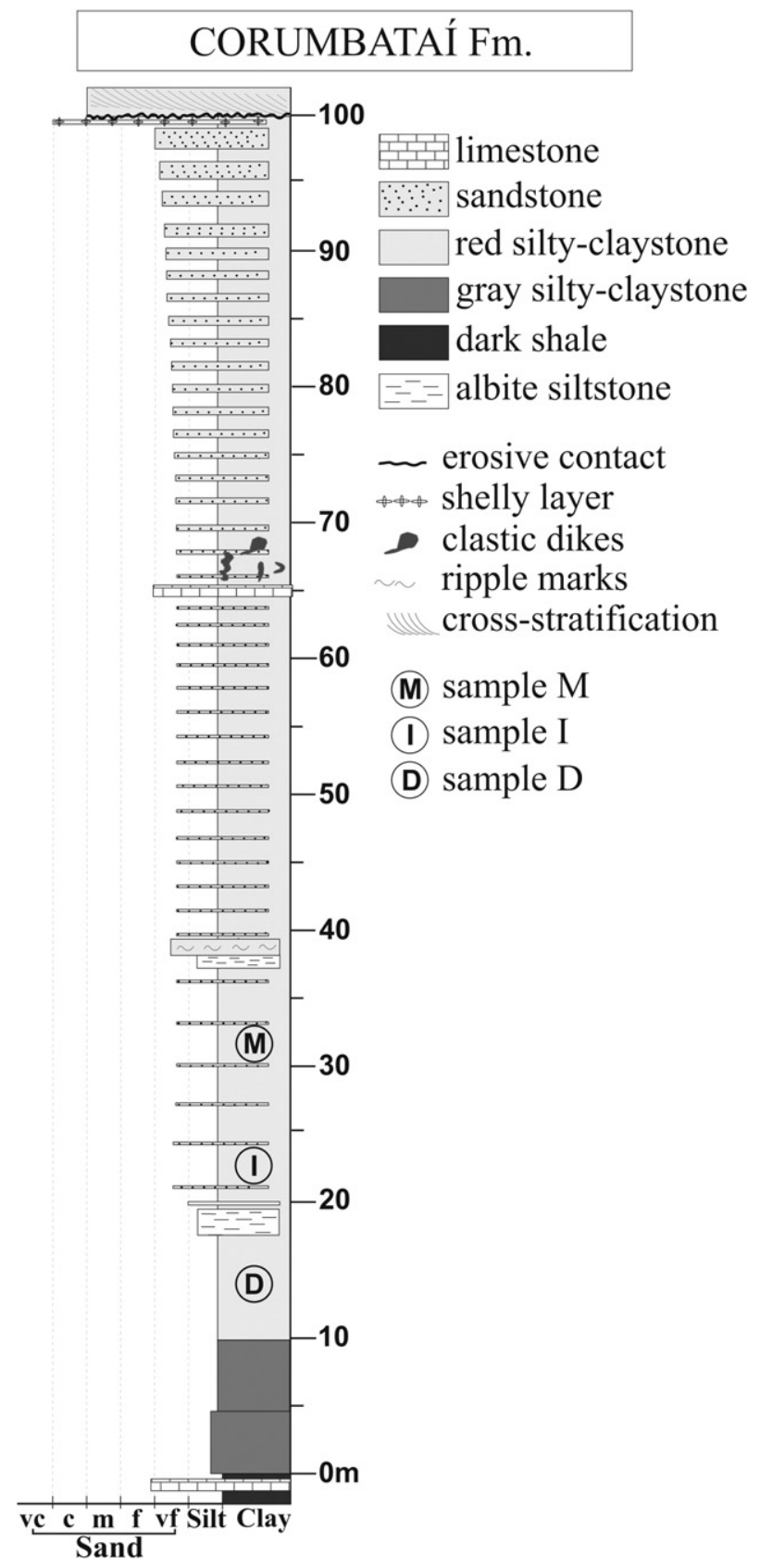

Fig. 2. Lithological column of the Corumbataí formation in the Ceramic District of Santa Gertrudes.

9.9 Å by EG treatment. The Ir index (Środoń, 1984) > 1 along with slight shift of the illite 001 reflection, indicated the presence of interstratified illite-smectite. The expandability $\left(\mathrm{S}_{\mathrm{XRD}}\right)$ of illite-smectite was calculated according to the method described by Środoń (1984). Overall, the results showed that all studied samples contained discrete illite and $R 3$ ordered illite-smectite with $<10 \%$ expandability.

The broad reflections at $\sim 7.47 \AA$ and $\sim 3.57 \AA$ in the air-dried XRD pattern from oriented preparations of the $\mathrm{Ca}^{2+}$ saturated, $<0.2 \mu \mathrm{m}$ fraction of sample $\mathrm{M}$ most likely contained a contribution from discrete kaolinite and kaolinite-smectite. The presence of interstratified kaolinitesmectite was confirmed by shift of the $\sim 7.47$ A reflection to $\sim 7.90 \AA$ by EG treatment. In addition, the position of reflection near $3.57 \AA$ shifted to the lower d-values after EG solvation. The expandability ( $\mathrm{S}_{\mathrm{XRD}}$ ) of kaolinite-smectite was determined to $30 \%$, according to the method described by Moore and Reynolds (1997). Significantly lower relative intensity of shoulder near $7.7 \AA$ and absence of reflection near $3.57 \AA$

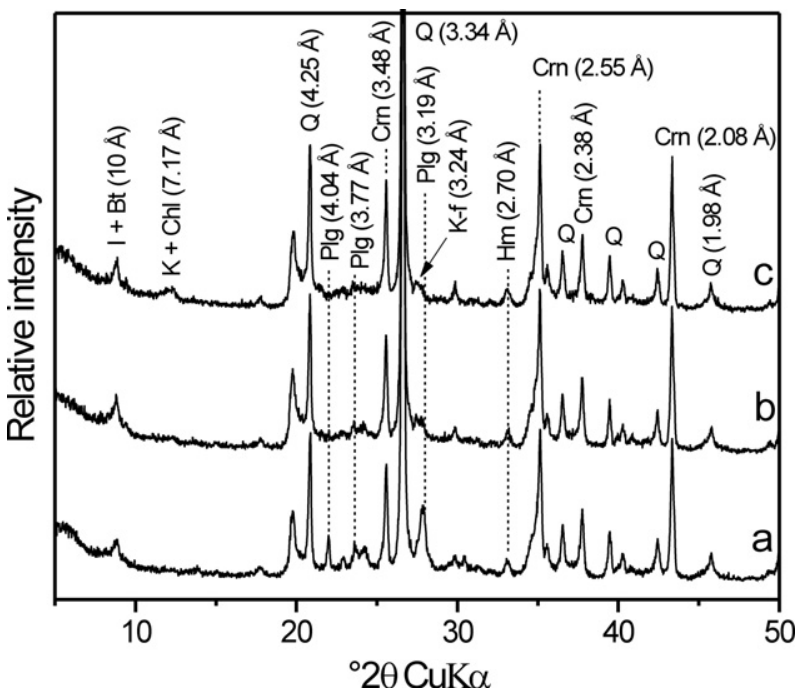

Fig. 3. XRD patterns for random preparations of bulk D (a), I (b) and M (c). I - illite, Bt biotite, $\mathrm{K}$ - kaolinite, Chl - chlorite, Q - quartz, Plg - plagioclases, K-f - K-feldspars, Hm - hematite, $\mathrm{Crn}$ - corundum (internal standard).

in the $\mathrm{Ca}^{2+}$ saturated, $<0.2 \mu \mathrm{m}$ fraction of sample I, suggested a relative lower amount of kaolinite and kaolinite-smectite for sample I compared with $\mathrm{M}$.

A simple test (heating to $550{ }^{\circ} \mathrm{C}$ for $1 \mathrm{~h}$ ) was performed on the oriented preparations ( $\mathrm{Ca}^{2+}$ saturated, $<2 \mu \mathrm{m}$ fraction) to confirm presence of kaolinite or chlorite in the studied samples. The absence of the reflections near 7.47-7.7 $\AA$ and $3.57 \AA$ after the test indicated the presence of kaolinite in the samples $\mathrm{M}$ and $\mathrm{I}$. The appearance of reflection near $14 \AA$ after the heating confirmed the presence of chlorite in the sample D. The presence of chlorite in the sample D was further clearly indicated in the XRD patterns from oriented preparations of the $\mathrm{Ca}^{2+}$ saturated 2-0.2 $\mu \mathrm{m}$ fractions by reflections near $14.2,4.74$ and $3.52 \AA$ (Fig. 4).

A comparison of the XRD patterns from oriented preparations of the $<0.2 \mu \mathrm{m}$ and $2-0.2 \mu \mathrm{m}$ fraction revealed that smectite and interstratified clay minerals (illite-smectite and kaolinite-smectite) were primarily concentrated in the finest fraction $(<0.2 \mu \mathrm{m})$ while chlorite, kaolinite and illite were more abundant in the coarser fraction $(2-0.2 \mu \mathrm{m})$ of the studied samples (Fig. 4).

However, it should be noted that the QXRD analysis (RockJock) was unable to separately quantify the amounts of illite, smectite and interstratified clay minerals. The QXRD was capable of measuring only the total 2:1 clay minerals content which is the sum of illite, smectite and interstratified illite-smectite. The relative amount of these clay minerals can be estimated from the relative intensity of its reflections in the XRD patterns from oriented preparations. Increased intensity of reflection near $10.1 \AA$ in the XRD pattern of $\mathrm{Ca}^{2+}$ saturated 2-0.2 $\mu \mathrm{m}$ fraction of sample D indicated higher amount of illite in this sample compared with the $\mathrm{M}$ and $\mathrm{I}$. The lowest amount of smectite was indicated in the sample I, based on the inspection of the $\mathrm{Ca}^{2+}$ saturated $<0.2 \mu \mathrm{m}$ fraction XRD patterns. The samples $\mathrm{M}$ and $\mathrm{D}$ contained a similar amount of smectite and illite-smectite. The highest amount of kaolinite-smectite was found in the sample $\mathrm{M}$.

\subsection{Chemical composition}

The chemical composition of the bulk D, M and I samples is reported in Table 1 . The highest amount of $\mathrm{SiO}_{2}$ in bulk $\mathrm{D}$ sample corresponded with highest amount of quartz + feldspars. Decreased $\mathrm{SiO}_{2}$ content and increased $\mathrm{Al}_{2} \mathrm{O}_{3}$ content in the bulk $\mathrm{M}$ sample may be related to the low amount of quartz + feldspars and high amount of clay minerals, respectively. The highest amount of $\mathrm{Na}_{2} \mathrm{O}$ in the bulk $\mathrm{D}$ sample was likely due to presence of plagioclases. A relatively higher $\mathrm{K}_{2} \mathrm{O}$ content found 
Table 1

Mineral and chemical composition of the bulk samples determined by RockJock and ICP analysis, respectively.

\begin{tabular}{|c|c|c|c|c|c|c|c|c|c|c|c|c|}
\hline \multicolumn{13}{|c|}{ Mineral composition (wt.\%) } \\
\hline & Quartz & Plagioclases & \multicolumn{2}{|l|}{ K-feldspars } & \multicolumn{2}{|l|}{ Hematite } & \multicolumn{2}{|c|}{ Kaolinite/kaolinite-smectite } & \multirow{2}{*}{$\begin{array}{l}\text { Chlorite } \\
1\end{array}$} & \multirow{2}{*}{$\begin{array}{l}\text { Biotite } \\
1\end{array}$} & \multicolumn{2}{|c|}{ Total 2:1 clays ${ }^{\mathrm{a}}$} \\
\hline M & 30 & 0 & 4 & & 2 & & 8 & & & & 5 & \\
\hline I & 30 & 2 & 6 & & 3 & & 2 & & 1 & 1 & 5 & \\
\hline $\mathrm{D}$ & 32 & 10 & 5 & & 3 & & 0 & & 4 & 1 & 4 & \\
\hline \multicolumn{13}{|c|}{ Chemical composition (wt.\%) ${ }^{\mathrm{b}}$} \\
\hline & $\mathrm{SiO}_{2}$ & $\mathrm{Al}_{2} \mathrm{O}_{3}$ & $\mathrm{Fe}_{2} \mathrm{O}_{3}$ & $\mathrm{Na}_{2} \mathrm{O}$ & & $\mathrm{K}_{2} \mathrm{O}$ & $\mathrm{MgO}$ & $\mathrm{CaO}$ & $\mathrm{MnO}$ & $\mathrm{P}_{2} \mathrm{O}_{5}$ & $\mathrm{TiO}_{2}$ & LOI \\
\hline M & 62.74 & 16.53 & 6.24 & 0.08 & & 2.98 & 1.67 & 0.16 & 0.05 & 0.07 & 0.68 & 8.60 \\
\hline I & 63.16 & 15.30 & 5.85 & 0.38 & & 3.86 & 2.20 & 0.24 & 0.06 & 0.07 & 0.65 & 8.00 \\
\hline $\mathrm{D}$ & 65.47 & 13.96 & 5.07 & 1.36 & & 3.41 & 2.42 & 0.90 & 0.06 & 0.17 & 0.58 & 6.40 \\
\hline
\end{tabular}

a The sum of illite, smectite and illite-smectite.

b From Azzi et al. (2015).

in all bulk samples may be related to the presence of K-feldspars and clay minerals (in particular illite). Clear differences in LOI among the bulk samples were likely due to variable amount and type of clay minerals. Increased LOI values observed for the bulk M and I were because of higher amounts of clay minerals, which is in agreement with the QXRD data. $\mathrm{Fe}_{2} \mathrm{O}_{3}$ content was mainly due to presence of $\mathrm{Fe}$ oxyhydroxides goethite (observed by optical microscope) and hematite (confirmed by XRD analysis), with possible contribution from clay minerals (illites, chlorites, smectites and biotite).

The chemical compositions of the bulk D, M and I samples were compared with the compositional groups provided for gres, majolica and cottoforte (Vincenzini and Fiori, 1976). All studied samples indicated suitability for the production of gres.

\subsection{Fourier transform infrared spectroscopy}

The infrared (IR) spectra for the bulk D, M and I samples and their $\mathrm{Ca}^{2+}$ saturated fine fractions $(2-0.2 \mu \mathrm{m}$ and $<0.2 \mu \mathrm{m})$ are shown in Fig. 5. The presence of clay minerals was clearly confirmed in all samples due to the absorption bands in the $3700-3620 \mathrm{~cm}^{-1}$ region. The broad absorption band near $3625 \mathrm{~cm}^{-1}$ was related to the stretching vibrations of structural $\mathrm{OH}$ groups of clay minerals present in the samples (i.e. illite, smectite, interstratified clay minerals, kaolinite and chlorite). The band near $3699 \mathrm{~cm}^{-1}$ belonged to the $\mathrm{OH}$ stretching vibrations of kaolinite outer surface $\mathrm{OH}$ groups. The relative amount of kaolinite can be estimated from the intensity of the $3699 \mathrm{~cm}^{-1}$ band (Russell and Fraser, 1994; Madejová et al., 2002). The relative intensity of this band increased, thus the amount of kaolinite increased, in the bulk samples in the order $\mathrm{D}<\mathrm{I}<\mathrm{M}$. This finding was in good agreement with the QXRD data (Table 1). The absorption near $3420 \mathrm{~cm}^{-1}$, present mainly in the finest fraction $(<0.2 \mu \mathrm{m})$ of all samples was due to $\mathrm{OH}$ stretching vibrations of water (interlayer water and water on the exterior surfaces of clay particles). The absorption near $912 \mathrm{~cm}^{-1}$, observed in the IR spectra of all samples, corresponded to $\mathrm{AlAlOH}$ bending vibrations of clay minerals. Two weak absorptions near 835 and $753 \mathrm{~cm}^{-1}$, visible in the spectra of the finest fractions $(<0.2 \mu \mathrm{m})$ of all samples, are diagnostic for illite and/or illitic component within an interstratified clay mineral structure (Russell and Fraser, 1994). The most intensive bands observed near 1168,1095 and $1028 \mathrm{~cm}^{-1}$ were attributed to Si-O stretching vibrations. While the absorption near $1020 \mathrm{~cm}^{-1}$ corresponded to $\mathrm{Si}-\mathrm{O}$ vibrations of clay minerals, the band near $1095 \mathrm{~cm}^{-1}$ indicated the presence of quartz. The bands near 520 and $470 \mathrm{~cm}^{-1}$ belonged to $\mathrm{Si}-\mathrm{O}-\mathrm{Al}$ and $\mathrm{Si}-\mathrm{O}-\mathrm{Si}$ bending vibrations, respectively. The 799, $778 \mathrm{~cm}^{-1}$ doublet, present in all samples, was due to Si-O stretching vibration of quartz. The intensity of the doublet substantially increased in the IR spectra of coarser fractions (bulk and 2-0.2 $\mu \mathrm{m}$ ) due to a relative higher amount of quartz, which is consistent with the XRD results. Bands characteristic of feldspars near 644 and $592 \mathrm{~cm}^{-1}$ were present only in the coarser fractions (bulk and $2-0.2 \mu \mathrm{m}$ ) of the sample D. The QXRD analysis confirmed the highest amount of feldspars (15 wt.\%, Table 1) for the sample D.

\subsection{Thermal analysis}

Fig. 6 shows the results of thermal gravimetric (TG), derivative thermal gravimetric (DTG) and differential thermal analysis (DTA). While the TG curves ideally show only weight changes during heating, the DTG curves show changes in the TG slope that may not be obvious from the TG curves. The DTA curves show the effect of energy changes (endothermic or exothermic) in the samples during heating.
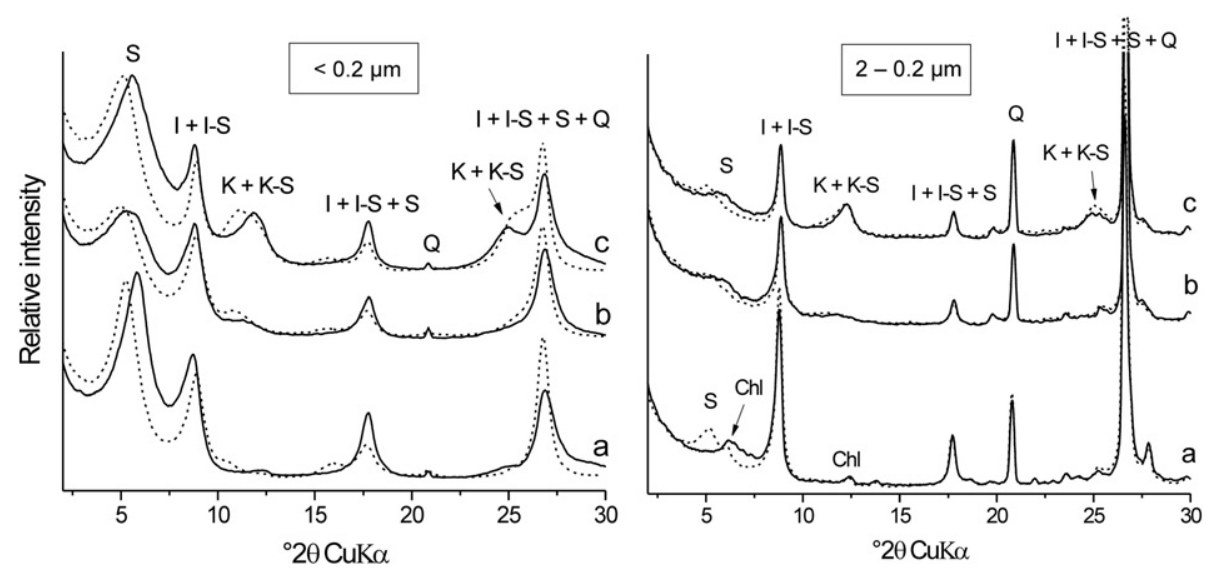

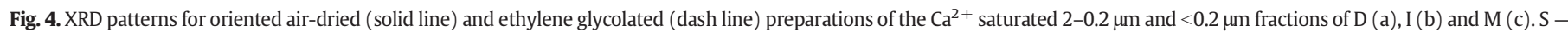
smectite, I - illite, I-S - illite-smectite, $\mathrm{K}$ - kaolinite, $\mathrm{K}-\mathrm{S}$ - kaolinite-smectite, Chl - chlorite, Q - quartz. 


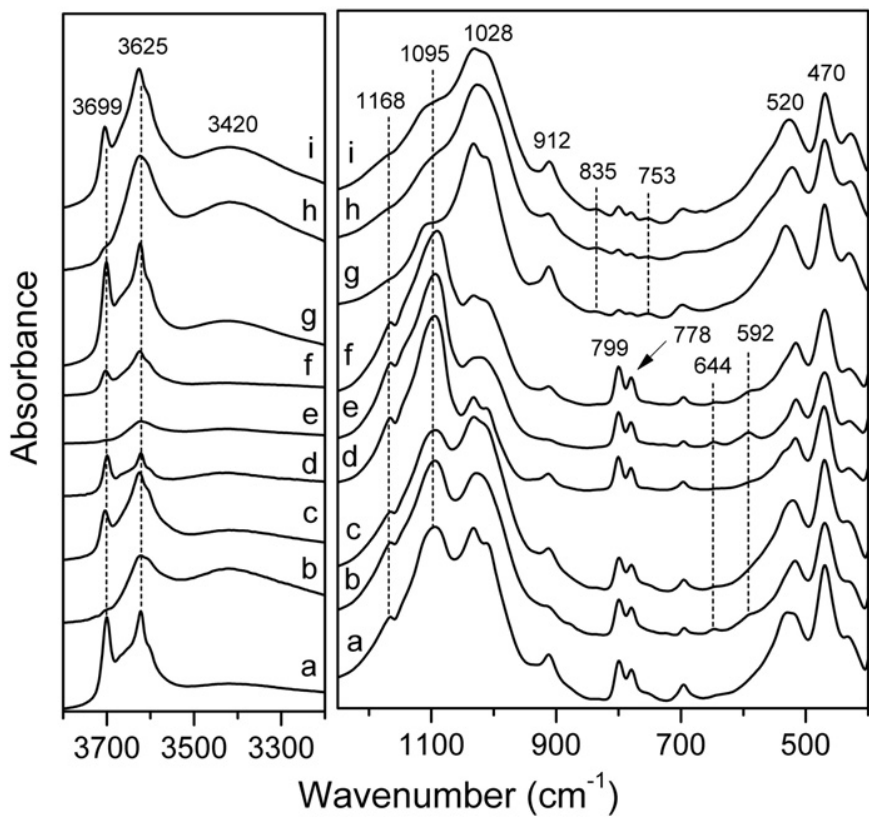

Fig. 5. IR spectra for bulk M (a), D (b), I (c), the $\mathrm{Ca}^{2+}$ saturated $2-0.2 \mu \mathrm{m}$ fractions for $\mathrm{M}$ (d), D (e), I (f) and the $\mathrm{Ca}^{2+}$ saturated $<0.2 \mu \mathrm{m}$ fractions for M (g), D (h) and I (i).

At low temperatures $\left(\leq 100^{\circ} \mathrm{C}\right)$, endothermic reactions related to desorption of surface water (e.g. water on exterior surfaces) and dehydration of water that is loosely held by exchangeable cations in the interlayer space of swelling clay minerals (i.e. smectite and interstratified clay minerals) (Ryan and Huertas, 2009) were observed in the DTA curves for all samples. Small endothermic peak near $180^{\circ} \mathrm{C}$ present only in the DTA curves of the finest fractions $(<0.2 \mu \mathrm{m})$ for D, M and I samples corresponded to the release of water directly coordinated to the exchangeable cations in the interlayer space of swelling clay minerals (Ryan and Huertas, 2009).
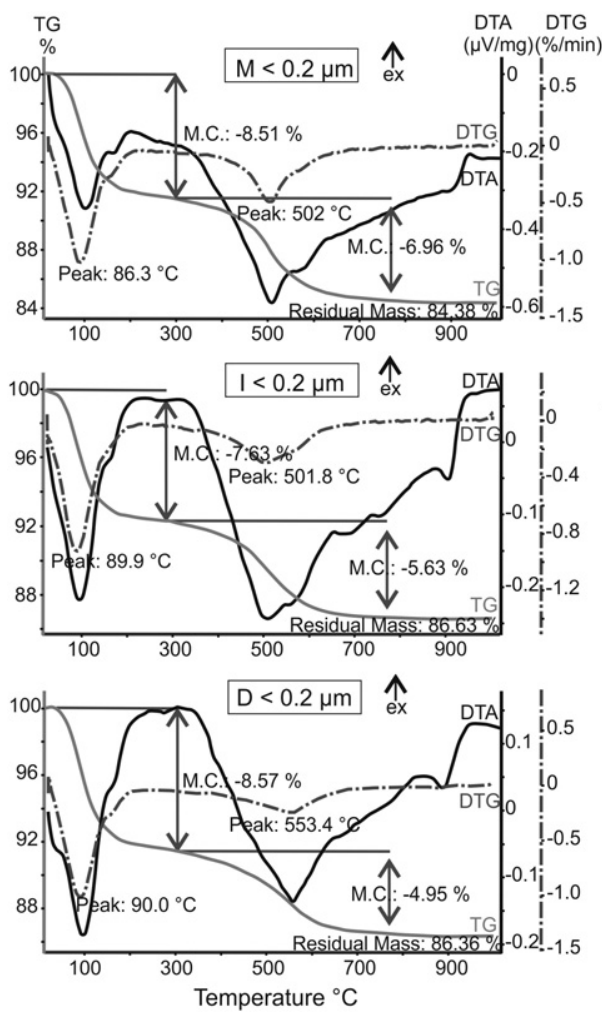

Fig. 6. TG, DTG and DTA curves for $\mathrm{Ca}^{2+}$ saturated fine fractions $(2-0.2 \mu \mathrm{m}$ and $<0.2 \mu \mathrm{m}$ ) of studied samples.

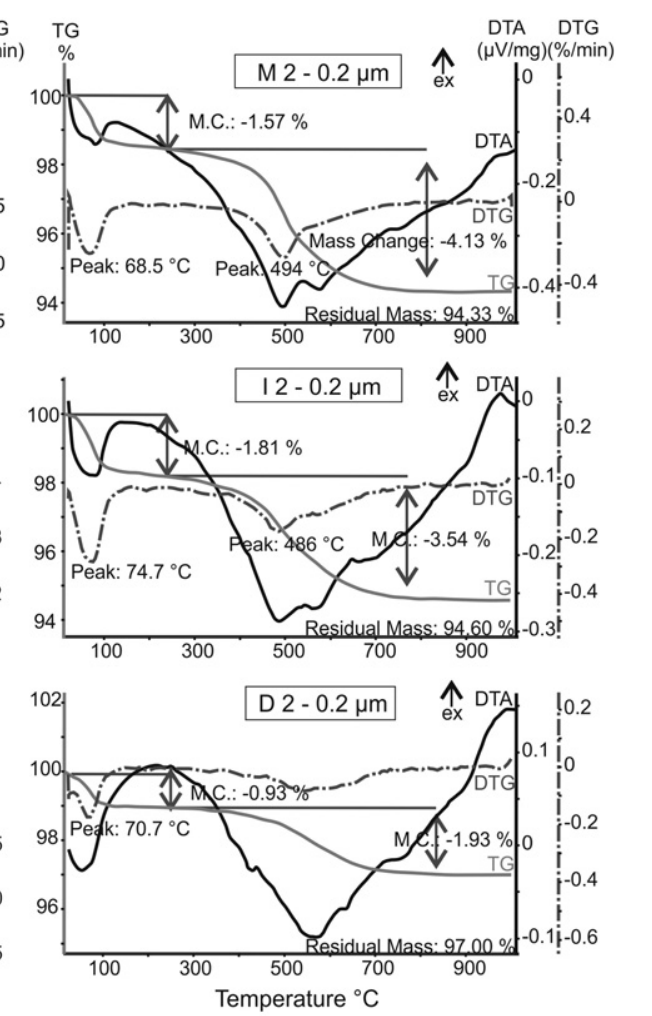

Clear differences were observed in the weight loss values (determined from the TG curves in the temperature range $~ 30-300{ }^{\circ} \mathrm{C}$, Fig. 6 ) for the different size fractions (2-0.2 $\mu \mathrm{m}$ vs. $<0.2 \mu \mathrm{m}$ ) of the studied samples. The weight loss values were from 4 to 9 times higher for the $<0.2 \mu \mathrm{m}$ fractions than for the $2-0.2 \mu \mathrm{m}$ fractions, likely due to higher amount of smectite and interstratified clay minerals (illite-smectite and kaolinite-smectite) in the finer size fractions. This conjecture was in agreement with the XRD results.

Thermal decomposition in the temperature range of $\sim 300-800{ }^{\circ} \mathrm{C}$ was mainly due to dehydroxylation (release of structural $\mathrm{OH}$ groups) of clay minerals. It should be noted that the endothermic shoulder near $300-800{ }^{\circ} \mathrm{C}$ in the DTA curves of all samples contained a contribution from all clay minerals present in the studied samples (i.e. illite, smectite, chlorite, kaolinite, illite-smectite and kaolinite-smectite). The DTA curves of most of smectites (montmorillonites) have one endothermic peak near $700{ }^{\circ} \mathrm{C}$ (Guggenheim and Koster van Groos, 2001) whereas illites dehydroxylate near $550{ }^{\circ} \mathrm{C}$ (Muller et al., 2000). Kaolinites typically exhibit dehydroxylation peak in the $510-520{ }^{\circ} \mathrm{C}$ (Guggenheim and Koster van Groos, 2001; Ryan and Huertas, 2009). Interstratified clay minerals (illite-smectites) are often characterized by two endothermic reactions near 500 and $700{ }^{\circ} \mathrm{C}$ (Mackenzie, 1957; Grim, 1968). An endothermic peak near $900{ }^{\circ} \mathrm{C}$ combined with an exothermic reaction above $900{ }^{\circ} \mathrm{C}$ in the DTA curves of all samples was attributed to the final destruction of the clay minerals (mainly illite and montmorillonite) lattice that preceded the formation of a high temperature phase (Grim and Rowland, 1942).

\subsection{Optical microscopy}

Petrographic study of thin sections revealed massive to faintly laminated structure of the bulk D, M and I samples. The samples were dominated by pelitic size fraction composed mainly of clay minerals. Psammitic fraction consisting mainly of quartz and feldspars grains $(<80 \mu \mathrm{m}$ in diameter) was less frequently present. Traces of muscovite, biotite, adularia, apatite, siliceous/phosphatic fossils, zircon, goethite and tourmaline were also found in the studied samples. 
Based on the optical microscopy, the amount of clay minerals in the samples D, I and M was estimated to about $50 \%, 60 \%$ and $65 \%$, respectively, which is in good agreement with QXRD data. Based on the classification of Shepard (1954) the samples I and M can be classified as silty clays. The grain size distribution classified the sample D as silty clay or clayey silt.

\subsection{Scanning electron microscopy}

SEM images of the polished thin sections prepared from bulk samples showed in all cases a number of large subhedral particles (typically several 10s microns in diameter) embedded in fine grained clay matrix (Fig. 7). The large particles were attributed mainly to non-clay minerals quartz and feldspars (plagioclases and K-feldspars). This assumption was in agreement with the EDX results which showed enrichment of some large particles in $\mathrm{Na}$ and $\mathrm{Al}$ suggesting the presence of feldspars (Fig. 7c, e). Bright elongated particles in the BSE images (Fig. 7b) enriched in $\mathrm{Mg}$ (Fig. 7f) were assigned to biotite. Atomic number contrast in the BSE images (Fig. 7b) was useful for identification of heavy elements-bearing minerals, since they appear brighter (relative to elements such as $\mathrm{Si}$ ) in BSE images. The BSE images from all bulk samples revealed a number of small (a few microns in diameter) bright anhedral and subhedral particles (Fig. 7b). These particles were attributed to Fe-bearing, or possibly to Ti-bearing minerals. The presence of hematite was confirmed by XRD analysis in all studied samples while a small amount of $\mathrm{TiO}_{2}$ minerals was indicated by chemical analysis.

\subsection{Transmission electron microscopy}

TEM images from the fine fractions $(2-0.2 \mu \mathrm{m}$ and $<0.2 \mu \mathrm{m})$ of the samples D, M and I showed that in all cases the particles were similar in shape. Most of the particles displayed lath-like, irregular or pseudohexagonal shape (Fig. 8a). Lath-like particles are characteristic of illitic particles (Hooshiar et al., 2012). Irregular anhedral morphology is typical of smectite whereas hexagonal particles are characteristic of kaolinite (Cuadros et al., 2009). Although the samples were prepared from the fully dispersed clay slurries the particles were found mainly in the form of aggregates.

Ultrathin sections of the $<0.2 \mu \mathrm{m}$ fraction from the samples D, I and $M$ were used for additional investigation on the nature of clay minerals by HRTEM. The number of layers per particle and the basal spacing were measured from HRTEM images for the $<0.2 \mu \mathrm{m}$ D and M samples (Fig. 9 ). Data on the number of layers per particle and the basal spacing were not available for the $<0.2 \mu \mathrm{m}$ I sample due to insufficient amount of particles in HRTEM images suitable for these measurements. The basal spacing of pure illite and pure smectite in epoxy resin was 11.05 and 1.25-1.30 nm, respectively (Vali and Köster, 1986; Środoń et
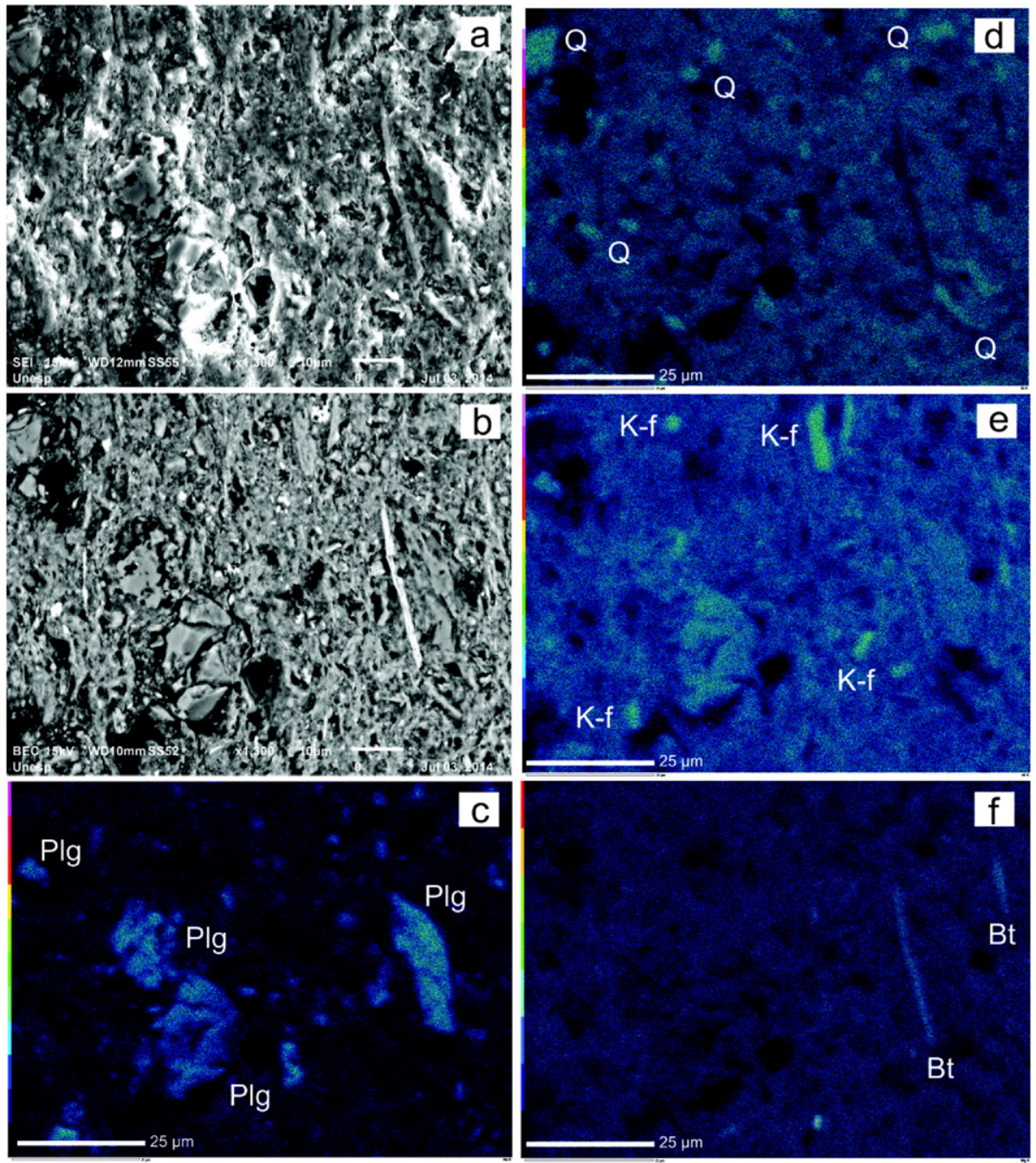

Fig. 7. SEM SE (a) and SEM BSE (b) images of sample D and corresponding EDX maps of Na (c), Si (d), Al (e) and Mg (f). Q - quartz, Plg - plagioclases, K-f - K-feldspars, Bt - biotite. 

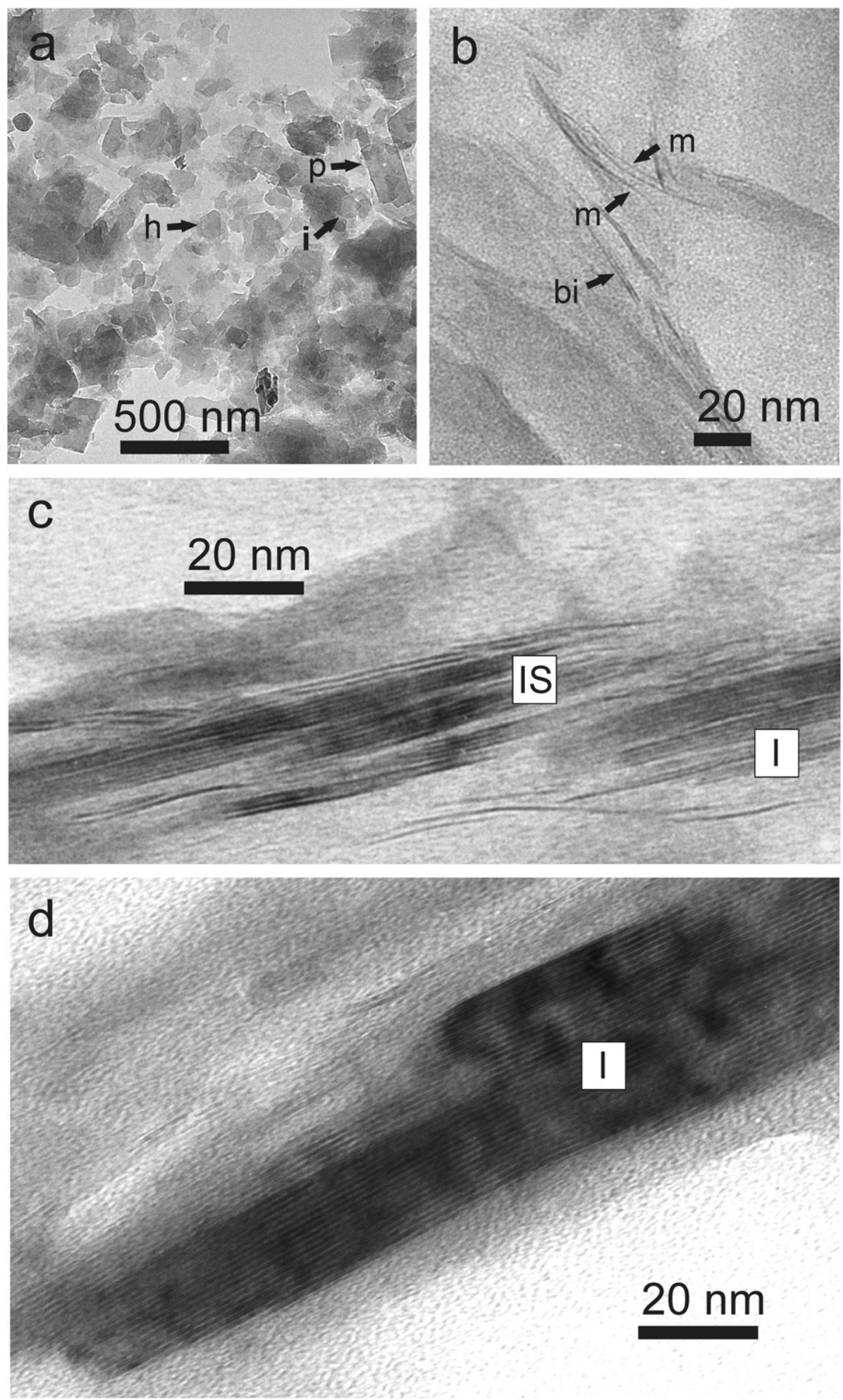

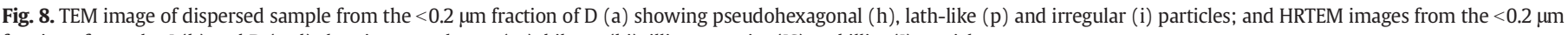
fraction of samples I (b) and D (c, d) showing monolayers (m), bilayer (bi), illite-smectite (IS) and illite (I) particles.

al., 1990). Any particles with basal spacing in the range of 1.05 to $1.25 \mathrm{~nm}$ were attributed to interstratified illite-smectite.

No significant differences were found between the basal spacing distributions of the D and M samples (Fig. 9a). Particles with the basal spacing corresponding to illite, smectite and illite-smectite were detected for both samples. HRTEM lattice fringe images of kaolinite and kaolinite-smectite were not observed in the samples likely due to high susceptibility of these minerals to electron beam damage (Robertson and
Eggleton, 1991). Particles with a wide range of lengths, from several ten to several hundred nm, were observed in all samples (Fig. 8). The number of particles representing the individual types of clay minerals was comparable for both studied samples (Fig. 9a). Both samples $(<0.2 \mu \mathrm{m} \mathrm{D}$ and $\mathrm{M})$ had a similar polymodal distribution of the number of layers per particle with peaks at around 1,5 and 10 layers and $\mathrm{N}_{\text {MEAN }}$ values (average number of layers per particle) around 4 (Fig. 9b). The polymodal character of the distribution was consistent with the 

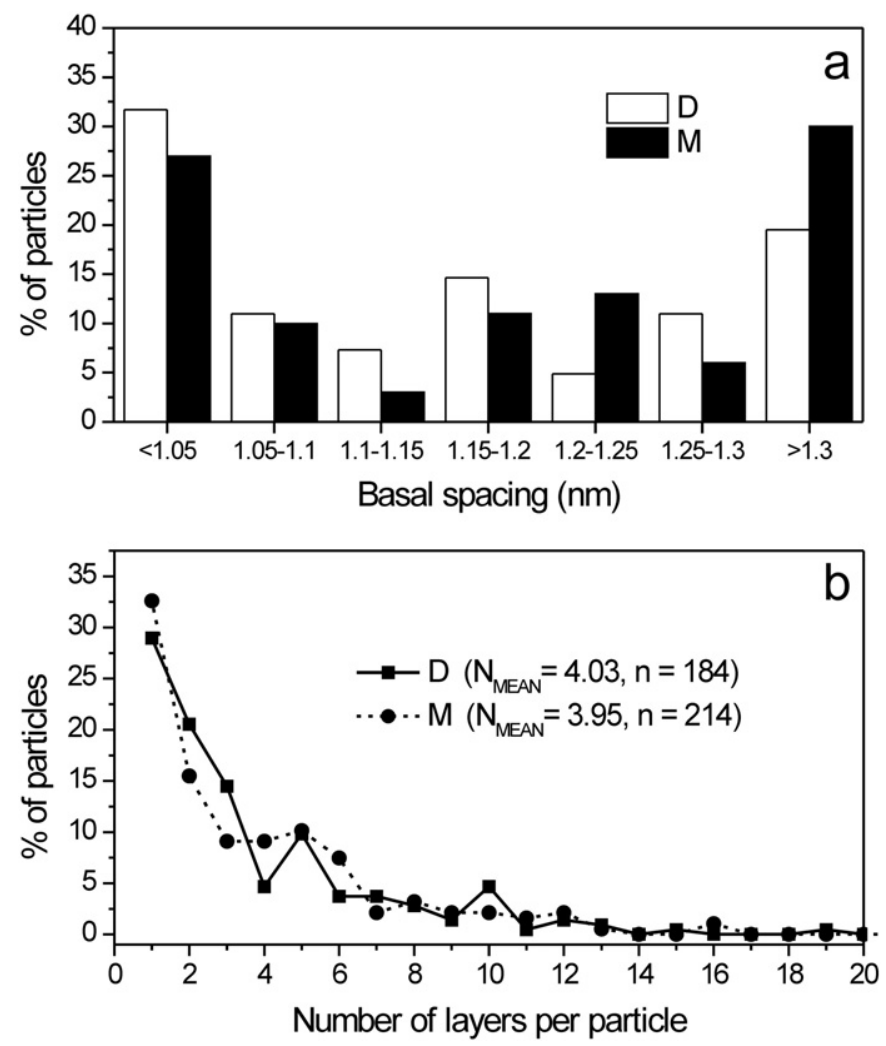

Fig. 9. Distribution of basal spacing (a) and number of layers per particle (b) measured from HRTEM images of the $\mathrm{Na}^{+}$saturated $<0.2 \mu \mathrm{m}$ fractions for $\mathrm{D}$ and M samples. $\mathrm{N}_{\text {MEAN }}$ - average number of layers per particle; $\mathrm{n}$ - number of measured particles.

polymineral clay composition of the studied samples, as observed by XRD analysis. Various clay minerals have different particle sizes. Chlorite, kaolinite and illite have usually thicker particle sizes than smectite and interstratified clay minerals (Środon, 2006). The $<0.2 \mu \mathrm{m}$ fraction of both samples showed a significant amount $(\sim 30 \%)$ of monolayers and bi-layer particles (15-20\%) (Fig. 9b). The monolayers were smectitic in nature while bi-layers can be attributed to both smectite and illite fundamental particles (Nadeau et al., 1984). Based on the basal spacing distributions, the particles with 4 layers per particle were assumed to be mainly illite-smectite, although it was not possible to exclude the presence of smectite and illite (Dudek and Środoń, 2003; Hooshiar et al., 2010). Thicker particles, with 8 or more layers per particle, were assigned to illite.

\section{Discussion}

The bulk samples consist mainly of clay minerals (from 49 to 63 wt.\%) associated with quartz (up to 32 wt.\%), feldspars (up to $15 \mathrm{wt} . \%$ ) and minor amount of hematite (up to $3 \mathrm{wt. \%}$ ) and biotite (up to $1 \mathrm{wt} . \%$ ). It should be emphasized that all studied samples are complex mixtures where 5 to 6 different types of clay minerals (illite, smectite, illite-smectite, kaolinite-smectite, chlorite, sometimes kaolinite) coexist in the same raw material used by the tile manufacturers in the CDSG.

The QXRD revealed differences in the amount of clay minerals among the studied samples. The lowest clay minerals content was observed for D (49 wt.\%), while higher clay minerals content was found for I ( $58 \mathrm{wt} . \%$ ) and M ( $63 \mathrm{wt} . \%)$. It indicates that the amount of clay minerals increases with higher degree of weathering of studied samples. The QXRD data were in good agreement with optical microscopy results which showed gradual increase in fine-grained clay matrix content for bulk samples (in the order $\mathrm{D}<\mathrm{I}<\mathrm{M}$ ) with increasing degree of weathering.
Overall, the results revealed different compositional features among the studied clayey raw materials. As a consequence, different technological behaviors are expected for these types of raw materials mainly due to variability, in terms of mineralogy (different types and amount of clay minerals) and compactness degree (different intensity of weathering).

Based on the technological classification of raw materials proposed by Dondi et al. (2014) the samples D, M and I can be classified as illite-rich (RC2) and/or illite-smectite (RC3) red clays. The RC2 types of red clays are in many cases silty clays, quite fusible but with a poor to moderate plasticity whereas R3 types are mostly silty clays, highly fusible, with moderate plasticity in case of chlorite-rich clays (Carretero et al., 2002) to high plasticity of the smectite-rich clays (Dondi et al., 2014). For both types (RC2 and RC3), the plastic behavior is also heavily affected by the amount of non-plastic component (e.g. quartz and feldspars) and also by the size fraction after grinding (Rocha, 2012).

In the ceramic tile industry, it is well known that clay mineralogy and particle size distribution of raw materials significantly affect behavior during tilemaking process involving properties like plasticity, drying sensitivity, slip viscosity, fusibility and pore-forming ability (e.g. Dondi, 1999; Stentiford, 2005; Ball and Fiederling-Kapteinat, 2007). Generally, raw materials containing a high amount of swelling clay minerals (interstratified clay minerals and smectite) are used in tilemaking as additives to enhance plasticity of too lean bodies and therefore may affect behavior mainly during pressing and drying (Dondi et al., 2014). Different degree of compactness of raw materials may affect particle size distribution and plasticity, thus the behavior during shaping and sintering (Alló et al., 1997; Dondi et al., 2014).

It is common in the industrial practice to use more than one source of clay raw material, flux and filler in order to eliminate any fluctuation in composition and technological properties. Tile manufacturers in the CDSG mix $10-30 \%$ of clayey rocks containing swelling clay minerals with other clayey raw materials from the Corumbataí formation (low amount or free of swelling clay minerals) in order to prepare batch of optimal composition.

The current dry route tilemaking process used in the CDSG has no significant constraints (except for environmental problems) when clayey raw materials are pre-treated by outdoor sunlight drying. However, replacement of outdoor sunlight drying of clayey raw materials by indoor forced drying using industrial dryers, had negative consequences on tilemaking process and product quality. Applying industrial dryers for pre-treatment of clayey raw materials involves higher drying temperature and shorter drying time compared with the outdoor sunlight drying. We believe that the different drying temperature and exposure time of clayey raw materials changed technological properties (e.g. particle size distribution and plasticity) of the tiles which consequently affected the quality of the finished ceramic products. To be able to explain different behavior of clayey raw materials from the Corumbataí formation pre-treated by outdoor sunlight drying versus indoor industrial driers, a detailed study focused on the effect of drying conditions on the properties (mineralogical and technological) of clayey raw materials and ceramic bodies are necessary.

The effect of different drying temperatures on the properties of clayey raw materials $\mathrm{D}, \mathrm{M}$ and $\mathrm{I}$ has been examined in an additional test, the results of which, we will report in a separate paper. The preliminary results of the test have shown that with increasing drying temperature the particle size distributions for D, M and I clayey raw materials shifted to the greater size fractions compared with the particle size distributions for the same raw materials dried by sunlight (Azzi, 2014). This indicates a presence of larger aggregates for clayey raw materials pretreated by force drying compared with those pre-treated by sunlight drying. The absence of larger aggregates for sunlight dried samples may be connected with disruption of large aggregates during maturation of raw materials in outdoor beneficiation areas. The large aggregates in clayey raw materials pre-treated by force drying were sufficiently stable to resist dry milling in hammer mill. Occurrence of such aggregates would unambiguously have reduced plasticity 
(aggregates behave as coarse grains i.e. non-plastic component) of raw material and may have negative consequences on shaping and pressing of the tiles, as documented by the results of several studies (Alló et al., 1997; Azzi, 2014; Moreno et al., 2014).

Other parameters affecting the plasticity of the material are hardness and clay minerals content (Alló et al., 1997). Higher hardness (due to low degree of weathering) and low clay minerals content for sample D decreased the plasticity and accounted for different shape of particle size distribution (shift to the higher particle sizes) compared with the samples M and I (Azzi, 2014). For these reasons, the most problematic technological behavior of all studied samples is expected for the sample D. This assumption was confirmed by results of Azzi (2014) showing the worst technological parameters (e.g. bending strength) for the tiles made up of clayey raw material D. The observations above are also in agreement with findings of Moreno et al. (2014) who reported that mineral composition and weathering degree of clayey raw materials from the Corumbataí formation affect the particle size distribution after milling which in turn influence the quality of the finished ceramic products.

We suggest that the main technological problems associated with the upcoming dry route tilemaking process in the CDSG are mainly due to the presence of aggregates which are formed by drying of clayey raw materials, using industrial dryers. In order to disrupt the aggregates, more aggressive milling is recommended for raw materials dried by industrial dryers than for those dried by sunlight. Disruption of aggregates increases plasticity which should have a positive effect on the behavior of the final bodies during tilemaking.

Alló et al. (1997) reported that storage of clayey raw material for several months under ambient climatic (weathering) conditions may increases the plasticity due to maturation effect. The aggregates are disrupted by the maturation and consequently smaller and more reactive particles are produced.

When additional aggressive milling and maturation of studied raw materials do not provide sufficient improvement in technological properties, then the addition of swelling clay minerals-bearing clay (plastic component) to problematic raw material is recommended. This treatment might be effective especially for samples with high hardness and low amount of clay minerals (i.e. low plasticity index; e.g. sample D). It has been shown that even small addition of swelling clay minerals (e.g. smectite) increases the plasticity index; however the improvement in technological properties heavily depends on how homogeneously the plastic and non-plastic components are mixed during milling procedure (Alló et al., 1997). It should be noted that technological behavior during tilemaking strongly depends on both, the nature of raw materials (mineralogy, chemistry, surface properties, particle size distribution, compactness degree, etc.) and the preparation of raw materials (drying, milling, homogenization, etc.).

\section{Conclusions}

The bulk samples contained a variable amount of clay minerals (illite, smectite, illite-smectite, kaolinite-smectite, kaolinite and chlorite), quartz, feldspars (plagioclases and K-feldspars), hematite and biotite. The bulk D sample contained higher amount of quartz (32 wt.\%) and feldspars (15 wt.\%) and lower amount of clays (49 wt.\%) compared with the bulk $\mathrm{M}$ and I samples. The clay minerals content was the highest (63 wt.\%) in the bulk M sample. The amount of clay minerals increased with a higher weathering degree of studied samples. The XRD patterns of oriented preparations revealed the highest relative amount of smectite and interstratified illite-smectite and kaolinite-smectite in the finest size fractions $(<0.2 \mu \mathrm{m})$. On the other hand, chlorite, kaolinite and illite were primarily concentrated in the coarser fractions (2$0.2 \mu \mathrm{m}$ ) of the studied samples. The expandability ( $\mathrm{S}_{\mathrm{XRD}}$ ) of interstratified illite-smectite and kaolinite-smectite was determined to be $<10 \%$ and 30\%, respectively. The TG curves showed from 4 to 9 times higher weight loss values for the finest fractions than for the coarser fractions confirming the higher amount of smectite and interstratified clay minerals in the finer size fractions.

Due to the distinct compositional features (different types and amount of clay minerals and different degree of compactness) among the studied samples, different technological behaviors are expected for these types of raw materials. The worst technological behavior expected for the less weathered sample D containing low amount of clay minerals and superior hardness was confirmed by published data. More aggressive milling of raw materials, addition of plastic component (swelling clay minerals) and homogenous mixing of plastic and non-plastic components are recommended to improve both, the technological behavior of the studied raw materials during tilemaking and the quality of the ceramic products. Storage of raw materials under ambient climatic conditions for a few months is also recommended due to maturation (tempering effect) of raw materials which may have a positive effect on tilemaking and product quality. However, outdoor storage of raw materials can be problematic in the CDSG mainly due to environmental issues (e.g. dust production).

\section{Acknowledgments}

The authors acknowledge the Slovak Grant Agency VEGA (grants: 2/ 0132/13 and 1/0301/14) and PDSE-CAPES scholarship (grant 2999/137) for providing research funding. The authors are grateful to the SEM laboratory staff at UNESP, Rio Claro for their help with SEM analysis. H. Pošvancová and G. Zatloukalová are acknowledged for their help with sample preparations.

\section{References}

Alló, W.A., Domínguez, E.A., Cravero, F., 1997. Precambrian yellow ilitic clay from La Siempre Verde pit, Barker, Buenos Aires, Argentina: plasticity improvement by preparation practices. Proc. 11th Int. Clay Conf., Ottawa, Canada, pp. 71-74.

ANFACER, 2014. Brazilian Association of Manufacturers of Ceramic Tiles, Sanitary Ware and Related Products, São Paulo. http://www.anfacer.org.br.

Azzi, A.A., 2014. A influência da temperatura na secagem forçada da matéria-prima cerâmica da Formação Corumbataí na região do Polo de Santa Gertrudes (SP) (Ph.D. Thesis, Rio Claro, Brazil: Universidade Estadual Paulista).

Azzi, A.A., Curtolo, M.Z., Zanardo, A., 2015. Sensibilidade à secagem da matéria-prima cerâmica da Formação Corumbataí na região do Polo Cerâmico de Santa Gertrudes, SP. Cerâmica 61, 236-243.

Ball, M., Fiederling-Kapteinat, H.G., 2007. The Mediterranean clay market for ceramic tile production in the past decade. Tile Brick Int. Man. 36-39.

Cabral Junior, M., Gamba, C.T.d.C., Tanno, L.C., Almeida, A.d.S., Cruz, T., 2013. Potencial das reservas de argila para o suprimento do polo cerâmico de Santa Gertrudes - SP : Onde o Recurso Mineral faz a Diferença. Ceram. Ind. 18, 10-16.

Carretero, M.I., Dondi, M., Fabbri, B., Raimondo, M., 2002. The influence of shaping and firing technology on ceramic properties of calcareous and non-calcareous illitic-chloritic clays. Appl. Clay Sci. 20, 245-254.

Cuadros, J., Nieto, F., Wing-Dudek, T., 2009. Crystal-chemical changes of mixed-layer kaolinite-smectite with progressive kaolinization, as investigated by TEM-AEM and HRTEM. Clay Clay Miner. 57, 742-750.

Dondi, M., 1999. Clay materials for ceramic tiles from the Sassuolo district (northern Apennines, Italy). Geology, composition and technological properties. Appl. Clay Sci. 15, 337-366.

Dondi, M., Raimondo, M., Zanelli, C., 2014. Clays and bodies for ceramic tiles: reappraisal and technological classification. Appl. Clay Sci. 96, 91-109.

Dudek, T., Środoń, J., 2003. Thickness distribution of illite crystals in shales. II: Origin of the distribution and the mechanism of smectite illitization in shales. Clay Clay Miner. 51, $529-542$.

Eberl, D.D., 2003. User's Guide to RockJock - A Program for Determining Quantitative Mineralogy from Powder X-ray Diffraction Data. U. S. Geological Survey, Boulder, Colorado.

Elsass, F., Beaumont, A., Pernes, M., Jaunet, A.-M., Tessier, D., 1998. Changes in layer organization of Na- and Ca-exchanged smectite materials during solvent exchanges for embedment in resin. Can. Mineral. 36, 1475-1483.

Grim, R.E., 1968. Clay Mineralogy: International Series in the Earth and Planetary Sciences. McGraw-Hill Book Company, New York.

Grim, R.E., Rowland, R.A., 1942. Differential thermal analyses of clay minerals and other hydrous materials. Am. Mineral. 27, 746-761 (801-818).

Guggenheim, S., Koster van Groos, A.F., 2001. Baseline studies of the clay minerals society source clays: thermal analysis. Clay Clay Miner. 49, 433-443.

Hooshiar, A., Uhlik, P.., Ivey, D.G., Liu, Q., Etsell, T.H., 2012. Clay minerals in nonaqueous extraction of bitumen from Alberta oil sands. Part 2: characterization of clay minerals. Fuel Process. Technol. 96, 183-194.

Hooshiar, A., Uhlík, P., Kaminsky, H.W., Shinbine, A., Omotoso, O., Liu, Q., Ivey, D.G., Etsell, T.H., 2010. High resolution transmission electron microscopy study of clay mineral 
particles from streams of simulated water based bitumen extraction of Athabasca oil sands. Appl. Clay Sci. 48, 466-474.

Mackenzie, R.C., 1957. The Differential Thermal Investigation of Clays. Mineralogical Society, London.

Madejová, J., Kečkéš, J., Pálková, H., Komadel, P., 2002. Identification of components in smectite-kaolinite mixtures. Clay Miner. 37, 377-388.

Milani, E.J., França, A.B., Schneider, R.L., 1994. Bacia do Paraná. Bol. Geocienc. Petrobras 8, 69-82.

Milani, E.J., Melo, J.H.G., Souza, P.A., Fernandes, L.A., França, A.B., 2007. Bacia do Paraná. Bol. Geocienc. Petrobras 15, 265-287.

Moore, D.M., Reynolds Jr., R.C., 1997. X-Ray Diffraction and the Identification and Analysis of Clay Minerals. second ed. Oxford Univ. Press, Oxford.

Moreno, M.M.T., da Rocha, R.R., Godoy, L.H., 2014. Major elements geochemistry of sedimentary rocks from Corumbataí formation, Santa Gertrudes Ceramic Pole, São Paulo, Brazil. Geomaterials 4, 11-17.

Motta, J.F.M., Christofoletti, S.R., Garcez, L.L., Florêncio, R.V.d.S., Boschi, A.O., Moreno, M.M.T., Del Roveri, C., Zanardo, A., 2007. Raw materials for ceramic tiles in the Santa Gertrudes Pole, Brazil. Interceram 56, 263-267.

Muller, F., Drits, V., Plancon, A., Robert, J.-L., 2000. Structural transformation of 2:1 dioctahedral layer silicates during dehydroxylation-rehydroxylation reactions. Clay Clay Miner. 48, 572-585.

Nadeau, P.H., Wilson, M.J., McHardy, W.J., Tait, J.M., 1984. Interstratified clay as fundamental particles. Science 225, 923-935.

Omotoso, O., Eberl, D.D., 2009. Sample preparation and data collection strategies for X-ray diffraction quantitative phase analysis of clay-bearing rocks. Proceedings of the 46th Annual Meeting of The Clay Minerals Society; 2009 June 5-11; Billings, Montana, USA. 209.

Petri, S., Coimbra, A.M., 1982. Estruturas sedimentares das Formações Irati e Estrada Nova (Permiano) e sua contribuicão para elucidacão dos seus paleoambientes geradores, Brasil. Actas Quinto Congreso Latinoamericano de Geologia 2, pp. 353-371.

Ramos, A.N., Formoso, L.L., 1976. Clay mineralogy of sedimentary rocks of the Paraná Basin, Brazil. Rev. Brasil. Geocienc. 6, 15-42.

Robertson, I.D., Eggleton, R., 1991. Weathering of granitic muscovite to kaolinite and halloysite and of plagioclase-derived kaolinite to halloysite. Clay Clay Miner. 36, 113-126.
Rocha, R.R., 2012. Propriedades químico-mineralógicas e cerâmicas de rochas da Formação Corumbataí: aplicação na diversificação de produtos (Ph.D. Thesis, Rio Claro, Brazil: Universidade Estadual Paulista).

Russell, J.D., Fraser, A.R., 1994. Infrared methods. In: Wilson, M.J. (Ed.), Clay Mineralogy: Spectroscopic and Chemical Determinative Methods. Chapman and Hall, London, pp. 11-67.

Ryan, P.C., Huertas, F.J., 2009. The temporal evolution of pedogenic Fe smectite to Fe-kaolin via interstratified kaolin-smectite in a moist tropical soil chronosequence. Geoderma 151, 1-15.

Shepard, F.P., 1954. Nomenclature based on sand silt-clay ratios. J. Sediment. Petrol. 24 $151-158$.

Sohn, I.G., Rocha-Campos, A.C., 1990. Late Paleozoic (Gondwanan) ostracodes in the Corumbataí formation, Paraná Basin, Brazil. J. Paleontol. 64, 116-128.

Środoń, J., 1984. X-ray powder diffraction identification of illitic materials. Clay Clay Miner. 32, 337-349.

Środoń, J., 2006. Identification and quantitative analysis of clay minerals. In: Bergaya, F. Theng, B.K.G., Lagaly, G. (Eds.), Handbook of Clay Science. Elsevier, Amsterdam, pp. 765-787.

Środoń, J., Andreoli, C., Elsass, F., Robert, M., 1990. Direction high resolution transmission electron microscopic measurement of expandability of mixed-layer illite/smectite in bentonite rock. Clay Clay Miner. 38, 373-379.

Środoń, J., Elsass, F., McHardy, W.J., Morgan, D.J., 1992. Chemistry of illite-smectite inferred from TEM measurements of fundamental particles. Clay Miner. 27, 137-158.

Stentiford, M.J., 2005. Industrial applications of kaolins and clays: general considerations and markets. Int. Ceram. J. 49-53 (June).

Šucha, V., Srodon, J., Zatkalíková, V., Francu, J., 1991. Mixed layered illite/smectite: separation, identification, use. Miner. Slovaca 23, 267-274.

Vali, H., Köster, H., 1986. Expanding behaviour, structural disorder, regular and random irregular interstratification of 2:1 layer-silicates studied by high-resolution images of transmission electron microscopy. Clay Miner. 21, 827-859.

Vincenzini, P., Fiori, C., 1976. Italian clays for the production of building material. Their characteristics and some technical properties. Ceramurgia 7, 119-134.

Zanardo, A., 2003. Pesquisa geológica e de matérias-primas cerâmicas do centro nordeste do estado de São Paulo e vizinhanças. Universidade Estadual Paulista, Rio Claro, Brazil. 